Оригинальные статьи / Original articles

https://doi.org/10.18619/2072-9146-2019-6-109-112 УДК 579.582.28:635.65

Куркина Ю.Н.

Федеральное государственное автономное образовательное учреждение высшего образования «Белгородский государственный национальный исследовательский университет» 308007, Россия, г. Белгород, ул. Победы, 85 корп. 14, ауд. 6-9, кафедра биотехнологии и микробиологии

E-mail: kurkina@bsu.edu.ru

Конфликт интересов: Автор заявляет об отсутствии конфликта интересов.

Благодарности. Автор выражает благодарность заведующей кафедрой биотехнологии и микробиологии НИУ БелГУ, профессору И.В. Батлуцкой за возможность проведения исследования, а также аспиранткам Нгуен Тхи Лан Хыонг и Нго Тхи Зием Киеу за техническую помощь в закладке опыта и технику кафедры А.С. Барсковой за техническую помощь в проведении лабораторного эксперимента.

Для цитирования: Куркина Ю.Н. Фенолоксидазная активность штаммов микромицетов, выделенных из ризосферы овощных бобовых культур. Овощи России. 2019:(6):109 112. https://doi.org/10.18619/2072-9146-2019-6109-112

Поступила в редакцию: 22.05.2019

Принята к печати: 14.06.2019

Опубликована: 25.11.2019

Yulia N. Kurkina

Federal State Autonomous Educational Institution of Higher Education «Belgorod State National Research University»

85, Pobeda Str., part 14, office 6-9,

Department of Biotechnology and Microbiology,

Belgorod, Russia, 308015

E-mail: kurkina@bsu.edu.ru

Conflict of interest: The author declare no conflict of interest.

Acknowledgments. The author is grateful to Professor, Head of the Department of Biotechnology and Microbiology, Belgorod State University, I.V. Batlutskaya for the opportunity to conduct research, as well as for graduate students Nguyen Thi Lan Huong and Ngo Thi Ziem Kieu fo technical assistance in laying the experience and equipment of the department A.S. Barskova for technical assistance in conducting a laboratory experiment.

For citation: Kurkina Yu.N. Phenoloxidase activity of micromycetes strains isolated from the rhizosphere of vegetable leguminous crops. Vegetable crops of Russia. 2019;(6):109-112. (In Russ.) https://doi.org/10.18619/2072-9146-2019-6-109-112

Received: 22.05.2019

Accepted for publication: 14.06 .2019

Accepted: 25.11.2019
Фенолоксидазная активность штаммов микромицетов, выделенных из ризосферы
овощных бобовых культур

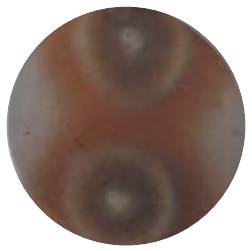

РЕЗЮМЕ

Актуальность. Микроскопические грибы проявляют наибольшую экзоферментативную активность, а ксилотрофны способны обладают комплексом оксидазных и гидролазных ферментов для разрушения лигнина.

Методы. Среди почвообитающих микромицетов, выделенных из ризосферы однолетних бобовых культур, проведен поиск штаммов, перспективных с точки зрения технологии эффективных микроорганизмов, для создания оптимальных условий повышения плодородия почвы и урожайности сельскохозяйственных культур. Выявление общей фенолоксидазной активности осуществляли по методу Бавендамма, культивируя штаммы на микробиологическом агаре с добавлением ароматического производного лигнина (0.06 \% танина) и вычисляли ростовой коэффициент. О целлюлазной активности штаммов судили по степени гидролиза фильтровальной бумаги. Выявлено, что штаммы Alternaria alternata, Bipolaris, Botrytis fabae, Cunninghamella echinulata, Curvularia lunata, Macrophoma phaseolicola, Trichoderma koningii, Trichoderma viride и Ulocladium botrytis способны расщеплять лигнин и целлюлозу.

Результаты. При сравнении фенолоксидазной активности штаммов предложено учитывать ростовой коэффициент, выражающийся отношением диаметра колонии на субстрате с добавлением танина к диаметру колонии без танина. Таким образом выделены перспективные по комплексной активности ферментов штаммы T. koningii и U. botrytis. Штаммы C.lunata, A. alternata и B. australiensis проявили высокую целлюлазную активность. Штамм непатогенного почвенного гриба C. echinulata обладает способностью к деструкции лигнина. Ключевые слова: ферменты грибов, фенолоксидазная активность, грибы ризосферы, овощные бобовые культуры, бобы, фасоль, арахис, вигна, болезни растений.

\section{Phenoloxidase activity of micromycetes strains isolated from the rhizosphere of vegetable leguminous crops}

\section{ABSTRACT}

Relevance. Microscopic fungi exhibit the greatest exoenzymatic activity, and xylotrophs are capable of possessing a complex of oxidase and hydrolase enzymes to destroy lignin.

Methods. Among the soil micromycetes isolated from the rhizosphere of annual leguminous crops, a search was made for strains that are promising from the point of view of effective microorganism technology, in order to create optimal conditions for increasing soil fertility and crop yields. The detection of total phenol oxidase activity was carried out according to the method of Bavendamm, cultivating the strains on microbiological agar with the addition of an aromatic lignin derivative $(0.06 \%$ tannin) and the growth factor was calculated. The cellulase activity of the strains was judged by the degree of hydrolysis of the filter paper. Alternaria alternata, Bipolaris, Botrytis fabae, Cunninghamella echinulata, Curvularia lunata, Macrophoma phaseolicola, Trichoderma koningii, Trichoderma viride and Ulocladium botrytis strains were found to cleave lignin and cellulose.

Results. When comparing the phenoloxidase activity of the strains, it was proposed to take into account the growth factor, expressed as the ratio of the diameter of the colony on the substrate with the addition of tannin to the diameter of the colony without tannin. Thus, perspective strains of $T$. koningii and $U$. botrytis strains with respect to the complex activity of enzymes were identified. The strains C. Iunata, $A$. alternata and $B$. australiensis showed high cellulase activity. The strain of non-pathogenic soil fungus $C$. echinulata has the ability to degrade lignin Keywords: enzymes of fungi, phenoloxidase activity, rhizosphere micromycetes, vegetable beans, beans, peanuts, vigna, plant diseases. 


\section{Введение}

вощные бобовые культуры пользуются обоснованным спросом во всем мире и не только входят в состав продуктов питания высокой биологической ценности (с высоким содержанием растительного белка, витаминов и микроэлементов), но и являются важным звеном в севооборотах (обогащая почву азотом). Кроме того, микофлора ризосферы бобовых культур может представлять интерес и с точки зрения технологии эффективных микроорганизмов, которая внедряется для сохранения и воспроизводства почвенного плодородия и нацелена на создание оптимальных условий для повышения урожайности возделываемых культур $[1,2]$. Благодаря таким прогрессивным технологиям с использованием биологических агентов, лигноцеллюлозные растительные отходы сельского хозяйства могут быть переработаны в ценные целевые продукты при снижении темпов загрязнения окружающей среды. Так, известно, что микромицеты проявляют наибольшую экзоферментативную активность и используют до 60\% субстрата на построение своих клеток, но только ксилотрофные грибы, обладая комплексом оксидазных и гидролазных ферментов, способны преодолеть лигнин, строение которого делает его труднодоступным для ферментных систем других микроорганизмов [3-7].

С другой стороны, сельскохозяйственные почвы накапливают фитопатогенное начало. В литературе проводятся данные о ферментативной активности фитопатогенных грибов, например, Fusarium, Bipolaris, Alternaria [8, 9]. При развитии инфекционного процесса патоген проникает в растение, задействуя именно ферментные комплексы. Поэтому среди многочисленных ферментов грибов особый интерес представляют те, которые необходимы для разрушения клеточной стенки растений. Известно, что способность микроскопических грибов синтезировать, например, целлюлазы, свидетельствует о патогенности [9, 10].

Способность некоторых патогенных грибов выделять различные ферменты исследована в ряде работ [9-11]. Однако число этих грибов невелико и патогены в данном аспекте исследованы недостаточно. В наших предыдущих исследованиях выявлены различия по видо- вому составу и численности микромицетов между образцами почв из-под разных бобовых [12], однако, микофлора ризосферы часто возделываемых овощных бобовых культур, как источников грибов-биодеструкторов, требует более детальных исследований. В связи с этим, целью данной работы явилось изучение фенолоксидазной способности микроскопических грибов, выделенных из ризосферы популярных овощных бобовых культур.

\section{Материал и методы исследования}

Исследованные грибы были выделены из ризосферы овощных бобов (Vicia faba L.) и фасоли (Phaseolus vulgaris L.), вигны (Vigna radiata L.) и арахиса (Arachis hypogaea L.). В качестве материала для исследований использовали почвенные образцы, отобранные в области ризосферы (0-4 мм). За каждый образец корневой почвы принимали не менее 10 растений одного вида без симптомов поражения болезнями, отобранных в период бутонизации - цветения с каждой опытной делянки в ботаническом саду НИУ «БелГУ». Почва исследованных участков - чернозем типичный, средний суглинок, мелкокомковатый по структурному составу, рН водной вытяжки (активная кислотность) на уровне 7,6; рН солевой вытяжки (обменная кислотность) - 6,9. Выделение грибов в чистую культуру проводили согласно общепринятым методикам [13], таксономическую принадлежность грибов определяли по совокупности культурально-морфологических признаков с помощью специальных руководств $[14,15]$

Выявление общей фенолоксидазной активности осуществляли по методу Бавендамма, для чего исследуемые штаммы культивировали на микробиологическом (голодном) агаре с добавлением ароматического производного лигнина (0.06 \% танина) и инкубации при температуре $25 \ldots 27^{\circ} \mathrm{C}$ в течение 10 суток. Штаммы с наиболее выраженной активностью (интенсивное образование пигмента) отбирали для последующего измерения диаметра колоний и вычисления ростового коэффициента (отношение диаметра колонии на субстрате с добавлением танина к диаметру колонии без танина) [3]. О целлюлазной активности штаммов судили по степени гидролиза фильтровальной бумаги, визуально

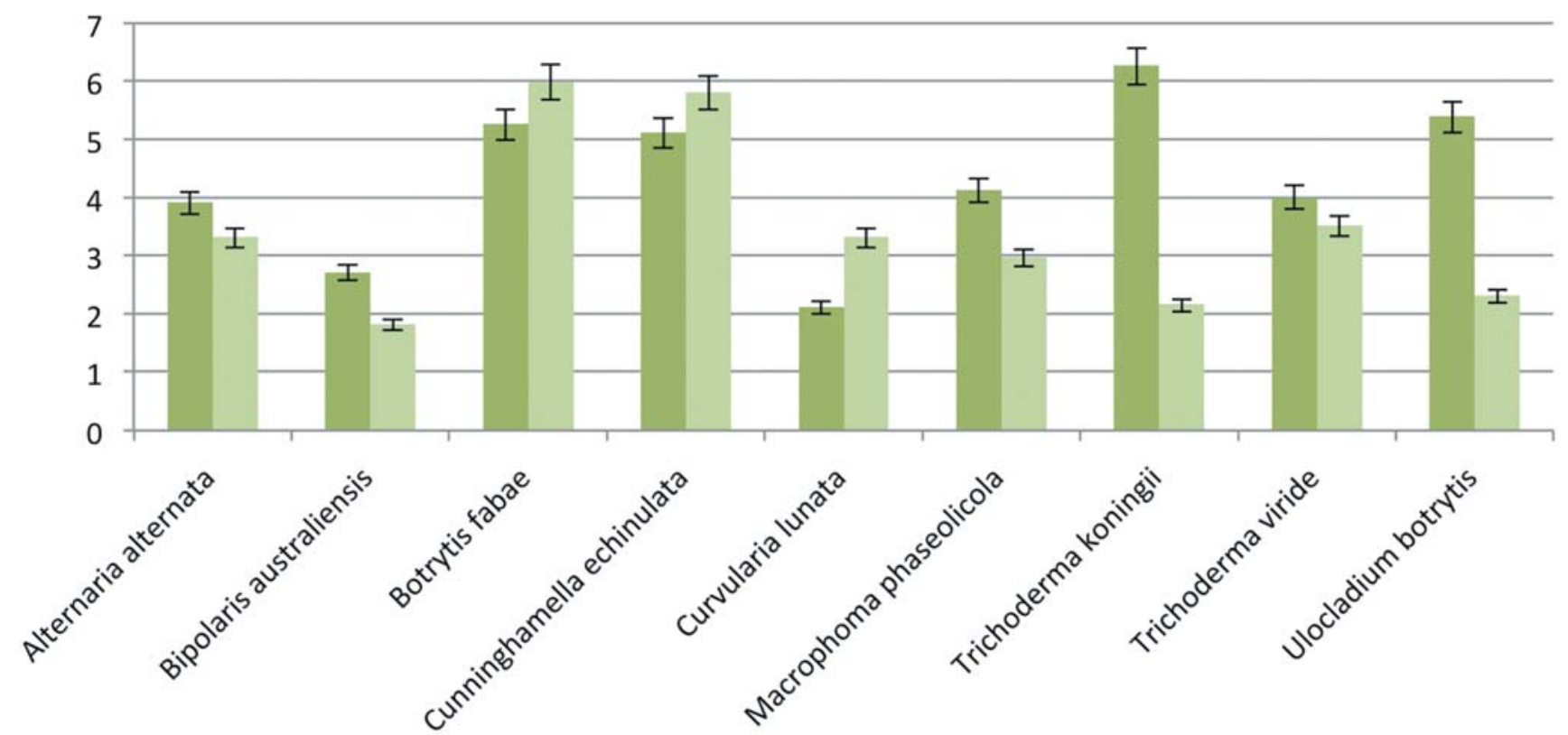

Рис. 1. Диаметр колоний микромицетов на агаре с добавлением 0.06\% танина (темный, левый столбец) и без добавления танина (светлый, правый столбец), планки погрешностей приведены с использованием 5\% значений Fig. 1. The diameter of the colonies of micromycetes on agar with the addition of $0.06 \%$ tannin (dark, left column) and without the addition of tannin (light, right column), error bars are given using $5 \%$ values 
отмечая ее разрушение по 5-балльной шкале на 14-е сутки [7].

\section{Результаты и их обсуждение}

В лаборатории микологии из ризосферы овощных бобовых культур выделены более 100 штаммов миркомицетов. Для определения ферментативной активности отобраны штаммы 9-ти видов (Alternaria alternata (Fr.) Keissl., Bipolaris australiensis (M.B. Ellis) Tsuda\&Ueyama, Botrytis fabae Sard., Cunninghamella echinulata Thaxter, Curvularia lunata (Wakker) Boedijn, Macrophoma phaseolicola L.A. Kantsch., Trichoderma koningii Oudem, Trichoderma viride Pers., Ulocladium botrytis Preuss), встречающихся в почвенных образцах большинства исследуемых культур и/или известных своими фитопатогенными свойствами [16-18].

Штаммы A. alternata, B. australiensis, M. phaseolicola,
T. koningii, T. viride, $U$. botrytis проявили реакцию Бавендамма, однако их радиальная скорость роста и ростовой коэффициент существенно различались (рис. 1, табл.).

Данные диаграммы свидетельствуют, что диаметр колоний B. fabae, C. echinulata, C. lunata на контрольной среде (без добавления танина) был достоверно больше, чем на питательной среде с танином, однако реакция Бавендамма отмечена и для этих видов. У остальных штаммов диаметр колоний, выросших на среде с танином, был достоверно выше, чем в контроле. Причем, визуальное проявление фенолоксидазной активности было наиболее выражено у представителей: T. koningii и U. botrytis (рис. 2).

Однако выделить образцы с достоверно большей среди изучаемых образцов грибов фенолоксидазной активностью, используя лишь диаметр роста колоний,
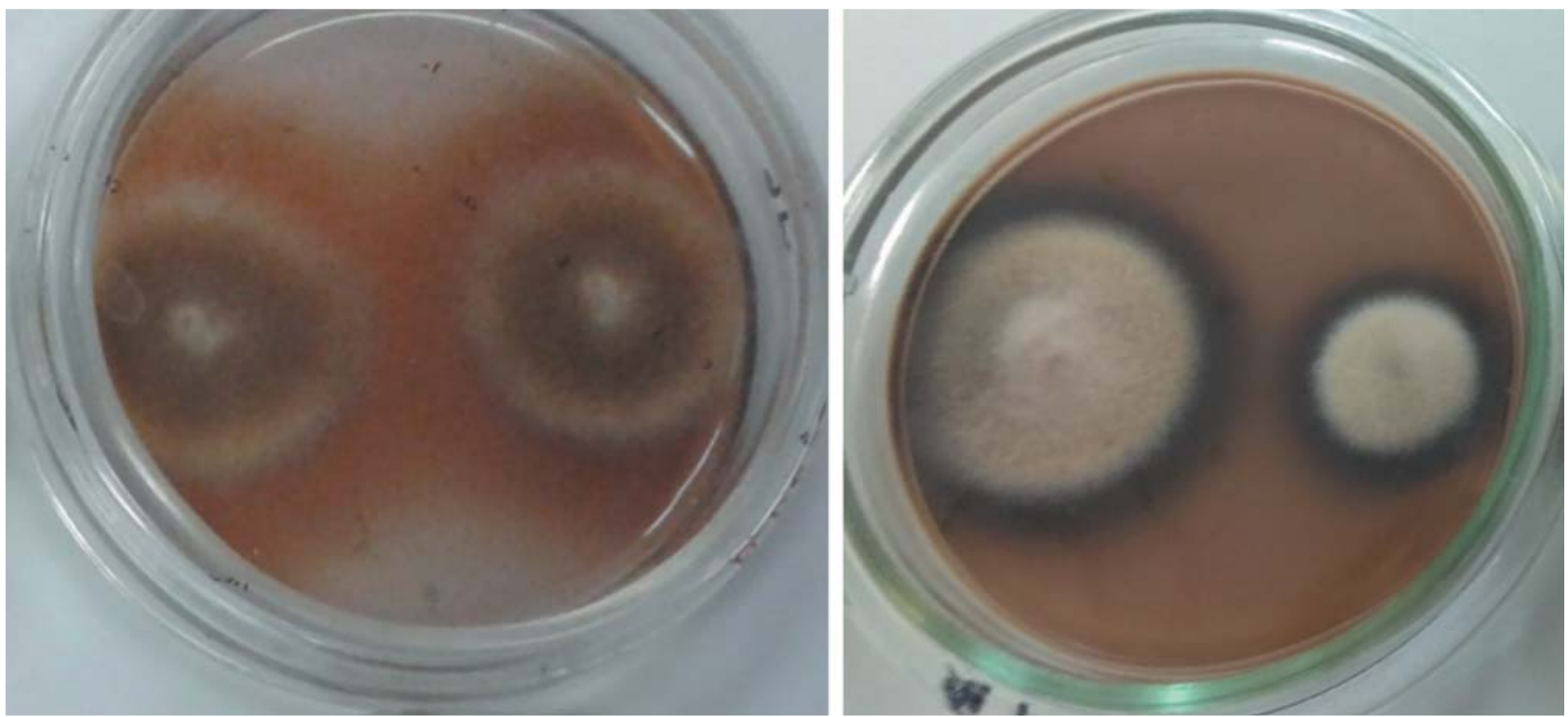

Рис. 2. Проявление реакции Бавендамма в чашках с Trichoderma koningii и Ulocladium botrytis, культивируемых на агаре $c$ добавлением танина

Fig. 2. The manifestation of the reaction Bevendamm cups with Trichoderma koningii and Ulocladium botrytis, cultivated on agar with the addition of tannin

Таблица. Значения ростового коэффициента проявление целлюлазной активности разных штаммов Table. The values of growth coefficient manifestation of cellulase activity of different strains

\begin{tabular}{|c|c|c|c|}
\hline $\begin{array}{c}\text { Виды } \\
\text { микромицетов }\end{array}$ & $\begin{array}{c}\text { Патогенность } \\
\text { штамма }\end{array}$ & $\begin{array}{c}\text { Ростовой } \\
\text { коэффициент при } \\
\text { определении } \\
\text { фенолоксидазной } \\
\text { активности }\end{array}$ & $\begin{array}{c}\text { Целлюлазная } \\
\text { активность, } \\
\text { балл }\end{array}$ \\
\hline Alternaria alternata (Fr.) Keissl. & ФП & 1.2 & 1.8 \\
\hline Bipolaris australiensis (M.B. Ellis) Tsuda \& Ueyama & ФП & 1.5 & 1.8 \\
\hline Botrytis fabae Sard. & ФП & 1 & 1 \\
\hline Cunninghamella echinulata Thaxter & НП & 1 & 0.5 \\
\hline Curvularia Iunata (Wakker) Boedijn & ФП & 0.6 & 3.8 \\
\hline Macrophoma phaseolicola L.A. Kantsch. & ФП & 1.4 & 2 \\
\hline Trichoderma koningii Oudem & НП & 2.9 & 1.8 \\
\hline Trichoderma viride Pers. & $\mathrm{H} \Pi$ & 1.1 & 3 \\
\hline Ulocladium botrytis Preuss & ФП & 2.3 & 4.7 \\
\hline
\end{tabular}

Условные обозначения: ФП - фитопатогенный, НП - непатогенный. 
представляется затруднительным. Ростовой коэффициент, средние значения которого представлены в таблице, позволяет провести ранжирование штаммов. Так, у штаммов $T$. koningii и U. botrytis ростовой коэффициент наибольший по опыту (соответственно 2.9 и 2.3).

Штаммы T. koningii и U. botrytis, которые могут представлять интерес для биотехнологии еще и высокой целлюлазной активностью, что согласуется с литературными данными [19]. Они могут быть использованы для улучшения технологии деградации отходов древесной промышленности. В сочетании с высокой целлюлазной активностью (4.8 баллов) грибы U. botrytis могут проявлять фитопатогенные свойства, которые доказаны для овощных форм бобов и фасоли $[17,18]$.

Вырабатывали большое количество целлюлаз, приводящих к деструкции фильтровальной бумаги, но при невысокой фенолоксидазной активности (см. таблицу), штаммы C. lunata (3.8 балла), A. alternata и B. australiensis (по 1.8 балла), которые могут найти применение при подборе продуцентов целлюлаз. Однако, штаммы с высокой активностью целлюзоразрушающих ферментов, согласно нашим данным, согласующимися с литературными $[9,10]$, могут представлять опасность для здоровых растений и это необходимо учитывать в разработке технологии защиты растений. С учетом этого, перспективным может стать непатогенный штамм C. echinulata, способный к деструкции лигнина,

\section{Об авторах}

Куркина Ю.Н. - кандидат с.-х. наук,

доцент кафедры биотехнологии и микробиологии но обладающий невысокой целлюлазной активностью и может быть рассмотрен в разрезе использования в составе препаратов - деструкторов стерни.

Способностью избирательно разрушать лигнин, не затрагивая ценную целлюлозную составляющую древесины (см. данные таблицы), обладали так называемые биоделигнификаторы, штаммы C. echinulata, B. fabae, M. phaseolicola.

Однако вопрос корреляции патогенности штаммов с комплексной ферментативной активностью микромицетов требует дальнейшего изучения.

\section{Выводы}

Таким образом, все изученные штаммы способны расщеплять лигнин и целлюлозу. При сравнении фенолоксидазной активности штаммов предложено учитывать ростовой коэффициент, выражающийся отношением диаметра колонии на субстрате с добавлением0.06\% танина (ароматическое производное лигнина) к диаметру колонии без танина, позволяющий выделить перспективные по комплексной активности ферментов штаммы $T$. koningii и $U$. botrytis. Штаммы $C$. lunata, A. alternata и B. australiensis проявили высокую целлюлазную активность. Особый интерес может представлять штамм непатогенного почвенного гриба C. echinulata, обладающий способностью к деструкции лигнина.

\section{About the authors:}

Yulia N. Kurkina - Ph.D. (Agriculture), Associate professor of the Department of Biotechnology and Microbiology

\section{- Литература}

1. Солдатенко А.В., Пивоваров В.Ф., Разин А.Ф., Мещерякова Р.А., Шатилов М.В., Иванова М.И., Тактарова С.В., Разин О.А. Экономика овощеводства: состояние и современность. Овощи России 2018;(5):63-68. https://doi.org/10.18619/2072-9146-2018-5-63-68.

2. Хрусталева Г.А., Аллахвердиев С.Р. Эффективные микроорганизмы и азотное питание растений. Успехи современного естествознания. 2014:8:28-30.

3. Рязанова Т.В., Чупрова Н.А., Лунева Т.А. Воздействие гриба рода Trichoderma на лигнин коры древесных пород. Катализ в промышленности. $2014 ; 6: 64-70$

4. Рогожин В.В. Практикум по биологической химии. СПб. 2006:256.

5. Санданова И.Б. Микробиологическая деструкция растительного опада степных экосистем юго-восточного Забайкалья: дисс. .кбн. 2007:127.

6. Казарцев И.А., Рощин В.И., Соловьев В.А. Разложение углеводов древесины Populus tremula и под действием лигнинразрушающих грибов. Микология и фитопатология. 2014:48(2):112-117.

7. Вырасткова К.А., Широких И.Г. Исследование природных изолятов микромицетов на целлюлозолитическую активность. Advancedscience. 2017;1:7.

8. Саданов А.К., Созинова Л.Ф. Клеточная селекция мягкой пшеницы на устойчивость к болезням. Астана. 2006:266.

9. Тагиманова Д.С., Хапилина О.Н., Созинова Л.Ф., Какимжанова А.А Изучение ферментативной активности фитопатогенных штаммов гриба Drechslera triticirepentis. Вестник КазНУ. Серия биологическая. 2014;1/2(60):349-351.

10. Еюбов Б.Б., Меджунова А.А., Гахраманова Ф.Х., Алиева Ф.А., Мамедова Ф.Р. Способность патогенных грибов выделять гидролитические ферменты. Вестник МГОУ. Серия Естественные науки. 2009;4:92-95.

11. Бицадзе Н.Г. Способность к выделению пектолитических, целлюлолити ческих ферментов и токсических веществ патогенным грибом Coniothyrium cerasi. Микология и фитопатология. 2006;40(5):433-437.

12. Нгуен Тхи Лан Хыонг Экологические особенности комплексов микромицетов травянистых растений семейства Бобовые (Fabaceae Lindl.) в условиях юга Среднерусской возвышенности: дисс...к.б.н. М. 2015:212.

13. Билай В.И., Элланская И.А., Кириленко Т.С. Микромицеты почв. Киев. 1984:264

14. Литвинов М.А. Определитель микроскопических почвенных грибов. Л. 1967:312

15. Пидопличко Н.М. Грибы-паразиты культурных растений: Определитель. Т.3. Пикнидиальные грибы. 1978:230.

16. Куркина Ю.Н. Патогенность штаммов ризосферных микромицетов бобовых культур. Защита и карантин растений. 2017;8:49-51.

17. Куркина Ю.Н. Болезни овощных бобов, вызываемые микроскопическими грибами. Овощи России. 2018;(3):99-104. https://doi.org/10.18619/2072 9146-2018-3-99-104.

18. Касатова Е.С. Активность экзооксидоредуктаз микроскопических грибов в связи с биодеструкцией ими природных и синтетических полимеров: автореф...к.б.н. Н.Новгород. 2011:18.

\section{- References}

1. Soldatenko A.V., Pivovarov V.F., Razin A.F., Meshcheryakova R.A. Shatilov M.V., Ivanova M.I., Taktarova S.V., Razin O.A. THE ECONOMY OF VEGETABLE GROWING: THE STATE AND THE PRESENT. Vegetable crops of Russia. 2018;(5):63-68. (In Russ.) https://doi.org/10.18619/2072-91462018-5-63-68

2. Khrustaleva G.A., Allahverdiev S.R. Effective microorganisms and nitrogen nutrition of plants. Successes of modern science. 2014:8:28-30.

3. Ryazanov T.V., Chuprova O.N, Luneva T.A. The effect of the fungus of the genus Trichoderma on the lignin of tree bark. Catalysis in industry. 2014;6:64-70

4. Rogozhin B.B. Workshop on biological chemistry. SPb. 2006: 256.

5. Sandanova I.S. Microbiological destruction of plant litter of steppe ecosystems of southeastern Transbaikalia: research..kbn. 2007: 127.

6. Kazartsev I.A., Roshchin V.I., Solovyov V.A. The decomposition of wood carbohydrates Populus tremula and under the action of lignindestructive fungi. Mycology and phytopathology. 2014:48 (2):112-117.

7. Vyrastkov K.A., Wide I.G. The study of natural isolates of micromycetes on cellulolytic activity. Advancedscience. 2017;1:7.

8. Sadanov A.K., Sozinova L.F. Cell selection of soft wheat for disease resistance. Astana. 2006: 266.

9. Tagimanova D.S., Khapilina O.N., Sozinova L.F., Kakimzhanova A.A. The study of the enzymatic activity of phytopathogenic strains of the fungus 2014;1/2(60):349-351.

10. Eyyubov B.B., Medzhunova A.A., Gahramanov F.H., Aliyev F.A. Mamedov F.R. The ability of pathogenic fungi to secrete hydrolytic enzymes. Bulletin of MGOU. A series of Natural Sciences. 2009;4:92-95.

11. Bitsadze N.G. The ability to isolate pectolytic, cellulolytic enzymes and toxic substances by the pathogenic fungus Coniothyrium cerasi. Mycology and phytopathology. 2006;40(5):433-437

12. Nguyen Thi Lan Huong. Ecological features of micromycetes complexes of herbaceous plants of the legume family (Fabaceae Lindl.) In the conditions of the south of the Central Russian Upland: Diss ... Ph.D. M. 2015: 212. 13. Bilay V.I., Alanskaya I.A., Kirilenko T.S. Micromycetes of soil. Kiev. Naukova dumka, 1984: 264 p. (in USSA).

14. Litvinov M.A. The determinant of microscopic soil fungi. L, 1967: 312

15. Pidoplichko N.M. Mushrooms-parasites of cultivated plants: Key. V.3. Pycnidial mushrooms. 1978: 230.

16. Kurkina Yu.N. Pathogenicity of rhizospheric micromycetes strains of legumes. Protection and quarantine of plants. 2017:8:49-51.

17. Kurkina Yu.N. Diseases of broad beans caused by microscopic fungi. Vegetable crops of Russia. 2018;(3):99-104. (In Russ.) https://doi.org/10.18619/2072-9146-2018-3-99-104.

18. Kasatov E.U. The activity of exo-oxidoreductases of microscopic fungi in connection with their biodegradation of natural and synthetic polymers: abstract of thesis ... Ph.D. N.Novgorod. 2011: 18. Drechslera triticirepentis. Herald KazNU. Biological series. 